\title{
The Relationship Between Hand Muscle Strength and Balance in Patients with Type 2 Diabetes Mellitus
}

\author{
Septian Andriyani*, Sehabudin Salasa, Lisna Anisa F, Afianti Sulastri, Linda Amalia, Upik Rahmi, Asih Purwandari \\ Program Study of Nursing, Faculty of Sport Education and Health \\ Indonesia University of Education \\ Bandung, Indonesia \\ *septianandriyani@upi.edu
}

\begin{abstract}
Type 2 diabetes mellitus is one of the metabolic diseases characterized by an increase in chronic blood glucose levels. It has a high risk of cardiovascular disease and other complications affecting the eyes, kidneys, and nervous system. Furthermore, the body cannot produce enough insulin. It would hamper the blood circulation and modify physical fitness, especially their body balance and muscle strength. Their muscle mass will decrease, which causes muscle weakness and fatigue. The condition can affect their daily life as well as their balance when they are walking. The purpose of this study was to determine the correlation between hand muscle strength and static balance in patients with type 2 diabetes mellitus. This study involved 47 older people with type 2 diabetes mellitus using a cross-sectional study design. Hand muscle strength of the elderly was measured by using a handgrip dynamometer, while static balance was measured through a single-leg stance test with their eyes open. The data were analyzed by Pearson correlation analysis. The results showed that the hand muscle strength and static balance had a strong correlation with Alpha coronach $=0,341$ ( $p$ value $=0,019$ ) in patients with type 2 diabetes mellitus. Furthermore, there is a significant relationship between hand muscle strength and balance in patients with type 2 diabetes mellitus.
\end{abstract} mellitus

Keywords: hand muscle strength, static balance, type 2 diabetes

\section{INTRODUCTION}

Diabetes mellitus is a chronic condition that occurs when blood glucose levels in circulation rise abnormally. In this condition, the body is unable to produce enough insulin or due to inadequate use of insulin [1]. In this condition, the pancreas does not produce enough insulin, or the body uses insulin ineffectively [2]. Complications that followed were a stroke, kidney failure, heart failure, nephropathy, and gangrene. Diabetes Mellitus type 2 is a significant public health problem; it's about 13 percent of the population worldwide having a diagnosis of diabetes, of which 90 percent is type 2. In North America, it costs about the US \$ 348 billion of the total regional health budget, which is equivalent to almost 14 percent [1]. Indonesia faces a situation similar to the threat of diabetes with the world.

The International Diabetes Federation (IDF) Atlas 2017 reports that the Diabetes epidemic in Indonesia is showing an increasing trend. Indonesia is the sixth-ranked country in the world after China, India, the United States, Brazil, and Mexico, with the number of people with diabetes aged 20-79 years around 10.3 million people.

The estimated incidence of diabetes mellitus in the world in 2015 is 415 million people. North America and the Caribbean have 44.3 million, South and Central America 29.6 million, Africa 14.2 million, Europe 59.8 million, West Pacific 153.2 million, Middle East, and North Africa 35.4 million inhabitants. The prevalence of diabetes mellitus in Southeast Asia is 78.3 million. Indonesia is ranked 7 th in the world with a prevalence of 10 million after China, India, the United States, Brazil, Russia, and Mexico. By 2040 the data is expected to continue to increase, where 1 in 10 adults will suffer from diabetes mellitus [1]. WHO 2016 reported that $70 \%$ of total deaths in the world, and more than half the burden of disease, about $90-95 \%$ of diabetes mellitus cases are type 2 diabetes mellitus. Mostly, it is caused by an unhealthy lifestyle [1]. Indonesia faces a similar situation in which diabetes as a threat. The International Diabetes Federation (IDF) Atlas 2017 reports that the Diabetes epidemic in Indonesia is showing an increasing trend. Indonesia is the sixth-ranked country in the world after China, India, the United States, Brazil, and Mexico, with the number of people with diabetes aged 20-79 years around 10.3 million people.

The estimated incidence of diabetes mellitus in the world in 2015 is 415 million people. There were in North America and the Caribbean about 44.3 million, South and Central America 29.6 million, Africa 14.2 million, Europe 59.8 million, West Pacific 153.2 million, Middle East and North Africa 35.4 million inhabitants. In line with it, the prevalence of diabetes mellitus in Southeast Asia is 78.3 million. Indonesia ranks 7th in the world with a prevalence of 10 million after China, India, the United States, Brazil, Russia, and Mexico. By 2040 the data is expected to continue to increase, where 1 in 10 adults will suffer from diabetes mellitus [1].

Based on primary health research data in 2013, West Java is a province whose population age 15 years above is diagnosed with diabetes more than $32,162,328$ people. $2.0 \%$ of them have never been diagnosed with diabetes, but one month past, they got any symptoms such as thirsty feeling, hunger, weight loss, and urination frequently - only $1,3 \%$ of people estimated and diagnosed with diabetes by doctors about 418,110 people [2]. Based on the diagnosis of the doctors, the prevalence of type 2 
diabetes mellitus in urban areas is $1.9 \%$ higher compared to rural areas, with a rate of $1.0 \%$ [3].

The tendency of diabetes mellitus in Bandung in 2015 relatively tended to increase compared to 2014 . The incidence of diabetes mellitus in 2015 reached 31,711 residents, while in 2014, it reached 24,301 residents [4]. The high number of people with diabetes mellitus is caused by, among others, factors such as lifestyle changes, increased incidence of obesity, decreased physical activity, and poor eating habits [5,6]. In patients with type 2 diabetes mellitus, exercise can have an impact on glycemic control, weight loss. VO2 max results increase with the use [7]. Movement and daily physical activity can improve strength, balance, aerobic capacity, and increase insulin sensitivity. Lower calorie intake, together with a higher level of activity, can cause weight loss that is simple but medically useful. A balanced diet, higher nutrient density, low salt levels, low glycemic levels, can lead to improved glycemic control and micronutrient status, and better blood pressure control. The Community facilitates adherence to prevention and therapeutics in achieving it through increased self-confidence and self-efficacy [8].

\section{METHODS}

This study uses a descriptive quantitative design to examine the correlation between muscle strength variable and static balance of the people with diabetes mellitus type 2. The population was taken from the Sukajadi Community Health Center's patient in Bandung, which is diagnosed with type 2 diabetes mellitus, involving 47 older people as respondents. We use instruments retrieved to collect data called a dynamometer handgrip to measure hand muscle strength and a balance test. The balance test is done by standing on one foot with closed eyes. Before the data collected, the respondents should sign the letter of agreement and informs consent as an understanding of the purpose, objectives, and research process. The data analyzed by correlation analysis.

Hand muscle strength test done on both hands left and right, alternately. The respondents ordered to stand relaxed, free arms released on the other side, while the arms may be slightly bent. Their hands must be dry, and the dynamometer handgrip is adjusted to the size of their hand and held comfortably. The second joint makes squeeze position, close under the handle, then they must squeeze as hard as possible between 2-3 seconds.

The balance test is done by standing on one foot with closed eyes comfortably while both of their arms at the waist. Then they instructed to lift one leg and place their toe on the knee next to it. The subject is later appointed to lift the heels and stand on tiptoes if ordered, and the time counting started. The time stopped counting if such of this condition happens, i.e., 1)one or both hands are dislodged from the waist; 2) the supporting leg is shifted in any direction; 3) when another foot is detached from the knee of supporting leg, or 4) if the heel of the supporting leg is open to the ground. This test is carried out three times to get an average value and minimize errors.

\section{RESULTS AND DISCUSSION}

The characteristics of respondents show in Table 1. The correlation test results (Table 2) showed the Pearson correlation value of $0.341(\mathrm{p}$-value $=0.019)$. This value shows that there is a significant relationship between variable hand muscle strength and balance. People who have diabetes mellitus have comparable muscle mass, but lower muscle performance and gait speed are significantly slower compared to those without diabetes mellitus. This condition is related to fitness in patients with type 2 diabetes mellitus and one indicator that can be used to determine the level of fitness [9].

TABLE I. CHARACTERISTICS RESPONDENTS

\begin{tabular}{|c|c|c|c|}
\hline \multirow{2}{*}{ Characteristics } & \multicolumn{3}{|c|}{$\begin{array}{l}\text { Frequency distribution } \\
\end{array}$} \\
\hline & Sub Characteristics & $\begin{array}{c}\text { Frequency } \\
(\boldsymbol{F})\end{array}$ & $\begin{array}{c}\text { Persentage } \\
(\%)\end{array}$ \\
\hline Gender & $\begin{array}{l}\text { Female } \\
\text { Male }\end{array}$ & $\begin{array}{l}35 \\
12\end{array}$ & $\begin{array}{l}74,5 \\
25,5\end{array}$ \\
\hline Age & $\begin{array}{l}45-59 \\
60-74 \\
75-90\end{array}$ & $\begin{array}{l}19 \\
21 \\
7\end{array}$ & $\begin{array}{l}40,4 \\
44,7 \\
14,9\end{array}$ \\
\hline $\begin{array}{c}\text { Body mass } \\
\text { index }\end{array}$ & $\begin{array}{l}\text { Less }(<18,5) \\
\text { Normal }(18,5-22,9) \\
\text { Escessive }(23-29) \\
\text { Obesity }(>30)\end{array}$ & $\begin{array}{l}1 \\
22 \\
19 \\
5\end{array}$ & $\begin{array}{l}2,1 \\
46,8 \\
40,4 \\
10,6\end{array}$ \\
\hline Sports & $\begin{array}{l}<3 x / \text { Week } \\
\text { 3-5/Week }\end{array}$ & $\begin{array}{l}36 \\
11\end{array}$ & $\begin{array}{l}76,6 \\
13,3\end{array}$ \\
\hline
\end{tabular}

TABLE II. Correlation Between Muscle Strength and Balance

\begin{tabular}{|c|c|c|c|}
\hline \multicolumn{4}{|c|}{ Correlations } \\
\hline & & Balance & Strength \\
\hline \multirow[t]{3}{*}{ Balance } & Pearson Correlation & 1 & $.341 *$ \\
\hline & Sig. (2-tailed) & & .019 \\
\hline & $\mathrm{N}$ & 47 & 47 \\
\hline \multirow[t]{3}{*}{ Strength } & Pearson Correlation & $.341^{*}$ & 1 \\
\hline & Sig. (2-tailed) & .019 & \\
\hline & $\mathrm{N}$ & 47 & 47 \\
\hline \multicolumn{4}{|c|}{ Correlation is significant at the 0.05 level (2-tailed } \\
\hline
\end{tabular}

Type 2 diabetes mellitus will cause pancreatic beta cells to be destroyed, causing insulin deficiency, which continues to decrease glucose use and make hyperglycemia after increasing blood viscosity and slowing its flow rate, which can follow an ischemic tissue. The rapid increase of diabetes has coincided with a change in environment and lifestyle associated with advanced industrialization and globalization, including more sedentary jobs, increased availability of sugary drinks and foods with high fat and salt content [10].

The occurrence of ischemic tissue causes the ineffectiveness of peripheral tissue perfusion and affects the strength of the muscle, which will decrease and make fitness drop. Factors that affect hand muscle strength and balance in patients with diabetes mellitus are genetic, gender, age, health status, nutritional status, and physical activity [11]. Movement, physical exercise, or sports have been proven to increase the use of glucose by cells, so that blood cave levels fall [12]. In this case, the balance can be interpreted as the ability to control the center of body mass or the center of gravity over a point or 
plane, as well as the ability to stand tall on two important legs in a person and as a precursor for the initiation of other activities of daily living, especially for the elderly [13].

Type 2 diabetes mellitus is a global problem that may cause harm and have an impact on fitness. In the book Margaret, et al. 2012 type 2 diabetes mellitus will cause pancreatic beta cells to be destroyed and then cause insulin deficiency which continues to decrease glucose use and make hyperglycemia after that will cause an increase in blood viscosity and cause blood flow to slow down, and there is an ischemic tissue. The occurrence of ischemic tissue will cause ineffective peripheral tissue perfusion and affect the strength of the muscle, which will decrease and make fitness decrease [11]. In patients with type 2 diabetes mellitus, exercise can have an impact on blood glucose control, weight loss, cardiovascular, liver, and overall $\mathrm{VO}_{2}$ max results in people with type 2 diabetes mellitus who exercise [7]. Exercise is a significant influence on reducing blood sugar and activity, including the pillar of control of type 2 diabetes mellitus, training is a considerable influence on the level of fitness of patients with diabetes mellitus. Disruption of the Quality of life of people with DM is influenced by several factors, including demographic status (age, sex, economic status), duration of diabetes mellitus, complications of diabetes mellitus (retinopathy, dental problems, sexual dysfunction), depression and also fatigue [14].

Fatigue in patients with type 2 diabetes mellitus can occur due to changes or disorders in physical and psychological functions related to the disease. Changes in bodily function that cause fatigue in people with DM is one of the cellular compensation processes to maintain cell function due to the impact of cellular starvation. Cellular starvation is a starvation condition experienced by cells because glucose is challenging to enter while around cells; there is much glucose. The compensation process occurs when muscle cells metabolize glycogen reserves to be dismantled into glucose and energy. This condition then has an impact on decreasing muscle mass, muscle weakness, and feeling tired quickly [14]. At the age of 30 years to 70 years and over will experience a decrease in strength and muscle size that shrinks by $30 \%$ due to decreased activity and increasing age. Muscle strength and endurance are interrelated so that the ability to contract muscles can be seen how much ability and endurance in the muscles [15].

Diabetes mellitus (DM) is a group of metabolic diseases characterized by hyperglycemia that can occur due to abnormal insulin secretion, insulin action, or both. Type 2 diabetes is the result of inadequate insulin production and the presence of insulin resistance, namely the body's inability to respond entirely to the hormone insulin. This diabetes is the most common type of diabetes; about $90 \%$ of all diabetes cases are type 2 diabetes. Most common in older age (older adults), but currently, there has been an increase in children, adolescents, and adults young. The disease is related to increased risk factors such as obesity, lack of exercise, and poor diet [1].

Based on the results of research from Umegaki.H, [9] shows that people who have diabetes mellitus have comparable muscle mass but for lower muscle performance and gait speed significantly slower than those who do not have diabetes mellitus. This condition is related to fitness in patients with type 2 diabetes mellitus and one indicator that can be used to determine the level of fitness [10].

Fitness is an ability to perform physical activities such as day-to-day activities efficiently without causing excessive fatigue so that they are still able to enjoy free time [17]. What is meant by fitness in the elderly must have fitness and physical health include heart and lung fitness, muscle flexibility, and muscle strength [17]. The benefits of fitness training are: Increasing the volume and strength of the heart, increasing the elasticity and efficiency of blood vessels, increasing the flexibility of the lungs, and making body proportions relatively proportional [18]. Components and indicators determine fitness by measuring cardiorespiratory endurance, strength (strength), muscle power (power), speed (speed), agility (agility), flexibility (flexibility), balance (balance), rate of reaction (reaction time) and coordination (coordination).

Besides, there are efforts to reduce the death rate and morbidity of type 2 diabetes that can be done by sufferers by regulating complex lifestyle changes such as regular medication adherence, diet control, physical exercise, blood glucose monitoring, and foot care $[19,20]$. People who have diabetes mellitus have comparable muscle mass, but lower muscle performance and gait speed are significantly slower compared to those without diabetes mellitus. This condition is related to fitness in patients with type 2 diabetes mellitus and one indicator that can be used to determine the level of fitness [9].

\section{CONCLUSION}

This study showed that most patients with Diabetes Mellitus type 2 had experienced muscle weakness. The condition has a significant effect on their body balance. Proper diabetes management is needed to maintain further severity to maintain the Quality of life of Diabetes Mellitus patients.

\section{REFERENCES}

[1] International Diabetes Federation, IDF Diabetes Atlas.Brussels: International Diabetes Federation, 2017.

[2] A. Castonguay and P. Miquelon, "Self-regulation resources and physical activity participation among adults with type 2 diabetes," Health Psychology, vol. 5, pp. 1-15, 2018.

[3] Riskesdas, "Hasil Utama riskesdas 2018," 2018, retrieved from: http://www.depkes.go.id/resources/download/infoterkini/materi_rakorpo p_2018/hasi1\%20riskesdas\%202018.pdf.

[4] Dinkes Kota Bandung, "penduduk diabetes mellitus," 2013, retrieved from: http://www.dinkeskotabandung.go.id//view/18121200001/preventprevent -and-prevent-the-voice-of-the world.

[5] Mp. Schwellnus, D.N. Patel, et al., "Healthy Lifestyle intervention in general practice part.4: Lifestyle and diabetes mellitus," South African Family Practice, vol. 51, no.1, 2009.

[6] B. Vessby, et al., "Diet, Nutrition and Diabetes Mellitus," Journal of Medical Sciences, vol. 105:2, pp. 151-160, 2011

[7] M. Quartuccio, "Sex differences in exercise performance and exercise training among persons with type 2 diabetes, 2017, retrieved from: https://link.springer.com/chapter/10.1007/978-3-319-61013-9_5.

[8] Ershow and G. Abby, "Environmental Influences on Development of Type 2 Diabetes and Obesity: Challenges in Personalizing Prevention and Management," Journal of Diabetes Science and Technology, vol. 3, issue 4, July 2009. 
[14] Nasekhah ad, "Hubungan kelelahan dengan kualitas hidup penderita diabetes Mellitus tipe 2 di Persadia," 2016, retrieved from: http://repository.poltekkes denpasar.ac.id/913/3/bab\%20ii.pdf .

[15] Ghomim, "Kebugaran Jasmani. fisiologi olahraga," 2017, retrieved from: http://www.Fisiologiolahraga.tk/2015/06/kebugaran-jasmani.html.

[16] Ichasanna, "Kebugaran dan olahraga," 2017, retrieved from: [online] http://www. Fisiologi olahraga.tk/2017/0 6/kebugara n-jasmani.html.

[17] Ichasanna, "Kebugaran dan olahraga," 2017, retrieved from: [online] http://www. Fisiologi olahraga.tk/2017/0 6/kebugara n-jasmani.html

[18] Palar, et.al., "Latihan olahraga," 2015, retrieved from: http://www. Fisiologi olahraga .tk/201 5/06/ kebugaran-jasmani.html.

[19] Chang, Lin, Chao, Yu \& Chen, "The Effectiveness of a diabetes selfmanagement program for diabetes patient in Taiwan," International Journal of Research In Medical and Health Sciences, vol. 4, no. 4, 2014.

[20] M. M. Funnell, T. L. Brown, B. P. Childs, L. B. Haas, G. M. Hosey, B. Jensen, L. M. Siminerio, "National standards for diabetes selfmanagement education," Diabetes care, vol. 31(1), pp. 97-104, 2008. 